\title{
The Sacralisation of the Battle of Poltava in the Eighteenth-Century Russian Empire*
}

\section{Introduction}

The calendars published in the late eighteenth-century Russian Empire, and assigning one date (or several dates) out of the year for each and every canonised saint to be remembered (svjatcy), included over 600 non-movable feasts. Among these, the one dated 27 June appears rather intriguing - "a feast about the victory over the Swedish king Charles XII at Poltava given by God to the All-Russian autocrat Peter the Great in the year I709 from Incarnation". Notably, the "victory" (pobeda) mentioned therein was the only nonreligious commemoration included in the Church calendar of the time. It goes without saying that appealing to God for His help neither turns a profane into a sacredly charged event nor can transform it into a Church feast, and even more so in the premodern period. Moreover, it can be understood from the passage above that the celebration for the success of Poltava was not being commemorated because of the work of the heavenly Powers (as, for example, in the case of the miraculous appearance of icons and the alike), but essentially as a strategic victory reaffirming tsarist authority.

In considering the arrangement and mechanisms beyond the lists of holy days, historians have long drawn attention to the political implications of the canonisation process (see, for instance, Chorošev 1986). The spread of cults, as Gary Marker has shown in respect to the cult of St. Catherine which in the Russian Empire was used to support and consolidate the newly established power of a (female) Empress, played an important part in state ideology (Marker 2007). The present paper analyses the way by which a secular event such as the battle of Poltava has been invested with religious meaning. More precisely, I investigate the reasons why during Catherine II's reign this military event acquired its own specific entry into the Church calendar, thereby embodying the features which Zitser attributed to what he calls 'political theology' of the Russian imperial throne (Zitser 2008). I also examine

* I would like to thank Nikolaos Chrissidis and Giovanna Brogi, who have been attentive readers of this text since its first drafts, for their useful remarks and generous help with proofreading. I am also grateful to Alex Petrocchi (University of Oxford) for her skillful copyediting and valuable comments.

I The original is in capital letters and reads: “праздникъ $\omega$ побъдь бгомъ дарованной Всєроссійскому Самодєржцу Пєтру вєликому надъ швєАскимъ королємъ кароломъ вторымнадєсАтъ Подъ полтавою 
the circumstances that led the Synodal Church to the sacralisation of the very victory over the Swedes at Poltava. For purposes of this study, I use the term 'sacralisation' to refer to the adaptation process which transforms and legitimises, with the consent of the Church hierarchy, a profane (either social or political) into a sacred event that reveals God's active participation and consequently becomes an object of religious and ritual worship. In other words, 'sacralisation' is the process of becoming or making 'sacred'. A key feature related to veneration and worship, in addition to Church authorisation and liturgical service, is the inclusion of the event in question in the Church Menologion (if a person is being canonised, an icon has to be painted). The analysis of the objectification and institutional concretisation of the 'victory' at Poltava as a sacred symbol has been mainly disregarded by historians. This paper aims to bridge this knowledge gap and demonstrate that such an investigation allows us to better comprehend the 'mobilising role' of Church holidays in the eighteenth-century Russian imperial policy: these proved to be, in fact, powerful and effective strategies for motivating and engaging the Orthodox population.

\section{Commemorating the Battle of Poltava: Its Entry in the Church Calendars}

In what follows, I first analyse the calendars appended to liturgical books (Gospels, Service books, books of Needs, and so forth) which were available to every parish. Such calendars were usually called 'Menologions' (mesjaceslovy), also referred to as soborniki or svjatcy, and included short lists of non-movable Church feasts (generally devoted to the saints) for every day of the year. They differed from the other types of Menologions which were published in the Russian Empire starting from the beginning of the eighteenth century. A Menologion was usually part of liturgical books used by the clergy, and was not printed separately. It contained lists of saints and sacred events, their status (solemn, ordinary, and so forth), and often a concise note regarding the format of their liturgical commemoration. Another type of Menologion was a kind of small publication providing details such as calendric information, business recommendations, astronomical data, weather forecasts, and so on addressed to a wide range of readers among the educated public. From 1726 the Holy Synod had been prohibited from printing these calendars, on the basis that their printing was not a Church affair (Pogosjan 200I: 337) ${ }^{2}$. This type of calendars (which were originally called mesjaceslovy, hereafter for convenience I will refer to them as 'civil' Menologions) contained, along with information about public state holidays, the lists of non-movable Church feasts of the liturgical year. Their information was second-hand and extremely concise compared to the Church calendars as only the most important dates were included. The civil Menologions contained also the lists of the state holidays, for instance the anniversaries of coronations, victories, birthdays of the members of the imperial family (so called "vysokotoržestvennye i tabelnye dni"). By contrast, these dates were not included

2 Notably, some pages earlier the author claims that in 1729-1730 the printing of calendars finally became the prerogative of the Academy of Sciences (Ibidem: 328). 


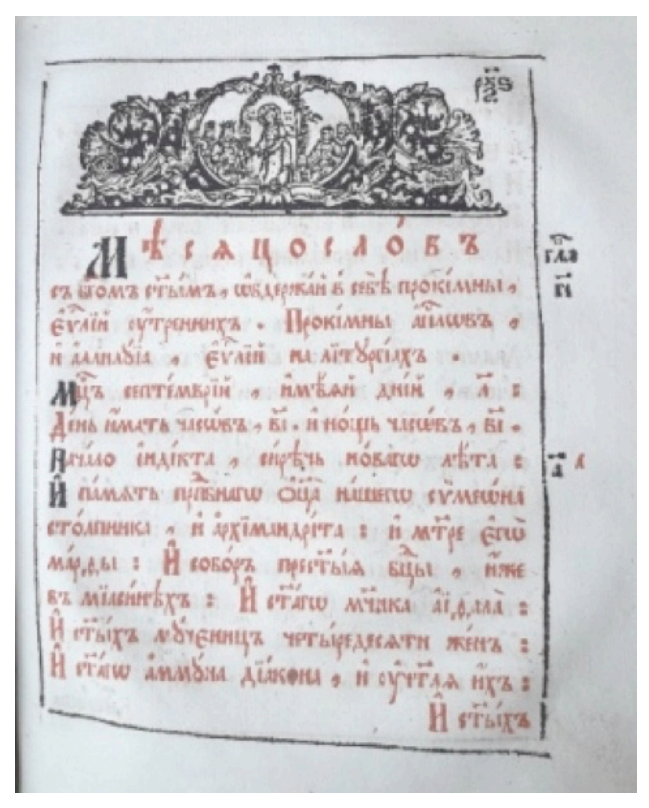

FIGURE I

The title page of a Church Menologion (Služebnik, Moskva 1763)

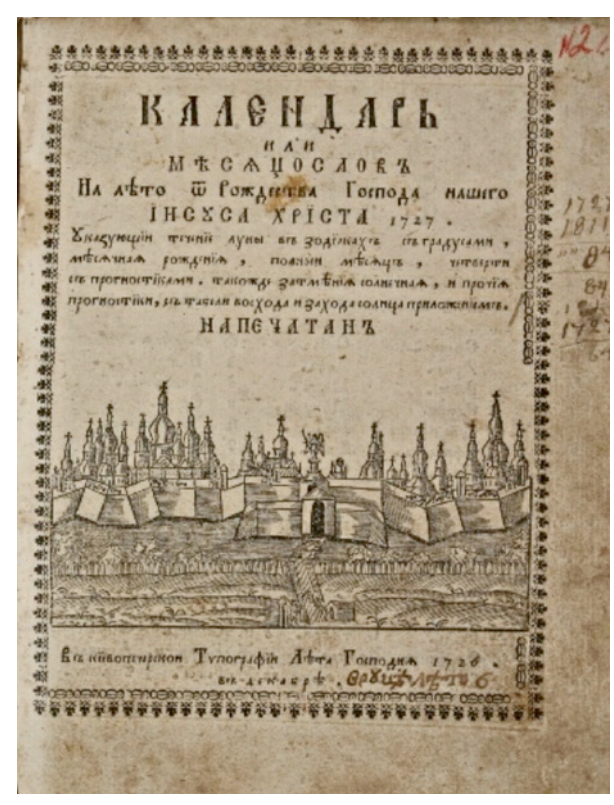

FIGURE 2

The title page of 1727 Kyiv civil Menologion

in the Church calendars. In this article, for practical reasons and as basis for comparison I use Church Menologions printed by different church typographies in the Russian Empire; the main focus remains, however, on the Moscow editions, since they were meant to serve as a model for other printing houses (cfr. FIGURES I and 2).

The practice of liturgical celebration of important political events (including international ones) and military battles was widespread in the eighteenth-century Russian Empire; for example, in response to a verbal order by Empress Elizabeth Petrovna, in September 1757 the Synod ordered that a service accompanied by pealing of bells be held on I9 August yearly in all dioceses in memory of the victory over the Prussian army3. Similarly, an order of 13 July 1776 deemed it necessary to include the date of July IO, which was the day of the conclusion of peace with the Ottoman Porte, into the list of highly solemn and victorious days, and to serve a thanksgiving prayer ("blagodarstvennoe molebstvie") with bell-ringing in all churches every year ${ }^{4}$. On the contrary, only the commemoration of the 'victory' at Poltava - an important event in the politics of imperial memory - had been included in the Church Menologions. 
In order to understand the wide implications of the inclusion of the Poltava battle in the Church calendar, it should be emphasised that the Church Menologion commemorates only the saints, miraculous icons, and events that are considered as sacred in themselves. Canonisation was the prerequisite for individuals to be included in the svjatcy; nevertheless, the commemoration of events which were considerate as reflecting divine intervention required a somehow less strict procedure. In Russia, both Church authorities and monarchs had this very power; for instance, the celebration of the Appearance of the icon of the Kazan' Mother of God in Moscow on 22 October and the protection of the city

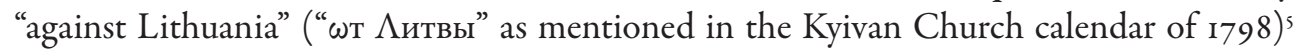
was sanctioned in Muscovy by Tsar Michail Fedorovic in I613 and confirmed by Tsar Aleksej Michajlovic in $1649^{6}$. Including the Poltava 'victory' in the svjatcy meant to elevate it to a status equal to that of other events of sacred history.

Despite sustained interest in the battle of Poltava, the fact and the way by which it has been added to the Church calendars has largely escaped the attention of scholars who, even when mentioning it, dedicate only one or two vague sentences to this important phenomenon. By way of illustration, Richard Wortman argues that in the Church calendars Peter I's victories were marked as feasts illustrating a new heroic history and also that Peter's greatest victories had been inserted in the Church calendar (Uortman 2002: 79, 95); the author, however, neither refers to primary sources nor provides any details to prove his claims convincingly. It remains, in fact, unclear what kind of calendars and 'victories' Wortman referred to; it seems likely that he mixed up commemorations in svjatcy and lists of "highly solemn" or "tabelnye" days in civil Menologions. Examining in detail the creation of a solemn calendar of events in the Russian state during the first half of the eighteenth century, Elena Pogosjan notes that sometime before 1712 Peter I mentioned the battle of Poltava in connection with the feast of St. Sampson, whose day of remembrance was 27 June. Notably, after 1712 this addendum (the reference to the battle of Poltava) to a religious event (that is to say the feast of St. Sampson) lost its relevance. The tsar celebrated 'victory' every year despite the circumstances (such as the death of tsarevich Aleksej Petrovič in 1718 on the eve of the forthcoming anniversary of the battle), but the Poltava day did not acquire a steady ideological signification until 1718, and only later "came to represent a 'Russian rebirth' for Peter. It was the anniversary of a military victory, much like the Old Testament holiday of Easter, and was invested with the significance of an event worthy of inclusion in the Church calendar. This explains the reason why the commemoration of the battle at Poltava acquired the right to become an independent annual holiday" (italicised by Pogosjan, M.Y.). Unfortunately, Pogosjan does not elaborate further to tell us whether the 'victory' day eventually became part of the Church Menologion; she only notes that the commemoration of the battle became a 'new center' for civil calendars compiled from 1719 onwards (Pogosjan 2001: I16-124, cit. I24). A.N.

\footnotetext{
AK 1798: 310.

6 ASBA: 6I $\left(\mathrm{N}^{\circ} 40\right)$.
} 
Kazakevič alludes to the insertion of the battle of Poltava in the Church Menologion in the early eighteenth-century very briefly and without references to sources or historical facts; also, despite the fact that his article's title mentions the commemoration of the battle by the Church, the author focuses instead on the construction of several churches and monasteries (Kazakevič 2009: 330). No less vague is N. Bolotina's assertion that from the first celebration of the victory in Moscow up to the end of 1709 "the holiday in commemoration of the Poltava victory entered the calendar of annual church celebrations": further in her account it becomes evident that she is concerned merely with public prayers and Church services (Bolotina 2009: 346; 2010: 292). The literature review here discussed demonstrates not only that all these brief and unsatisfactory statements clarify nothing about the inclusion of the battle of Poltava in the Church calendars, but also that they obscure the sacralisation process at the heart of the 'victory'.

The first step of the analytical approach I propose involves determining when the reference to the 1709 victory over the Swedes was first mentioned in the calendars. My investigation reveals that the time it took to insert 'victory' in the Church Menologions was longer compared to its inclusion in the civil calendars, which took place shortly after the event itself and was located in various rubrics. There is no need here for me to underline the ideological significance of commemorating the battle of Poltava which, perhaps not surprisingly, later came to serve as a starting point for calculating time. No reference to Poltava in the short list of Church feasts contained in the civil Menologion for the year 1710 is found but, when considering how to divide the year I710, the compilers used the date of the battle, which had recently occurred, as a reference point: "[It is] the seventh month since the victory of Peter I over the Swedish king Charles XII at Poltava"' There is no 'victory' in the laconic list of the June Church feasts in a similar edition for the year $17 \mathrm{II}^{8}$; it is only in the calendar published in November I7II for the year $17 \mathrm{I} 2$ that the "victory" appear in brackets under June 27 after the reference to St. Sampson: "[On this day occurred the victory over the Swedes at Poltava]". By the time of the appearance of the civil Menologion for the year $17 \mathrm{I} 8$, the standard phrase commonly found had been: "[Memory] of rev. Sampson and of the feast on the victory over the Swedes" ${ }^{\text {"10 }}$.

No 'victory' is mentioned in the calendars by the St. Petersburg press for the years between 1718 and 1721,1728 , and $1731^{11}$, but it was included in the 1722 Moscow civil Menolo-

7 “Отъ вікторіі полученыя надъ свьіскімъ королемъ каролусомъ, г2. подъ Полтавою, 7, мъсяць” (кмсh г710: s.n. [2, 7 v.]). This is the second calendar of this type in Russia (the first appeared in 1708 and was meant for the year 1709) and the first in which the victory at Poltava is mentioned as one of the calendar starting points (Pogosjan 200r: 146).

8 KMCh i7II: s.n. (7 v.).

9 “[въ сеи день бъ побъда на шведа под полтавою]” (кмсh і7І2: s.n. [7 v.]).

Iо “Преп: сампсона, и празд: о побъдђ надъ шведы” (кмсh і7і 8: s.n. [7 v.]).

II KiM I7I8: s.n. (I2 v.); KiM I719: s.n. (I2 v.); KiM I720: s.n. (I2 v.); KiM I72I: s.n. (I2 v.); KiM I728: s.n. (II v.); KMIG: s.n. (II v.). 
gion $^{12}$ and in the 1728 last Moscow edition. One finds 'victory' back in the main part of Petersburg's civil calendars only in 1733 (Pogosjan 2001: 333, 343). A similar situation is found in editions of Menologions-manuals with prognostication published separately in Kyiv; we find an entry for Poltava under 27 June in the calendar published in 1713: after the reference to the feast of St. Sampson the sentence "Victory over the Swedes" is found ${ }^{13}$. By contrast, in the 1727 Lavra's calendar the battle was used to guide readers through a chronological list of events and historical processes which included the Creation of the world, Noah's flood, the destruction of Sodom and Gomorrah, the beginning of the Babylonian, Persian, Greek and Roman 'monarchies', the Exodus (“исхожденіА Ісраілтескаго”), the baptism of Old Rus' prince Volodymyr, the invention of gun powder and printing, the coronation of Empress Catherine Alekseevna, the birth of her grandson prince Peter, the beginning of the Russian fleet and, finally, the Poltava "victory" (“ свъіискімъ Королємъ Каролусомъ вторымънадєслтъ, подъ Полтавою”) the Poltava battle is neither mentioned in the list of Church feasts of Lavra's Menologion for year $1727^{15}$ nor in the edition for $1730^{16}$.

In the Russian civil Menologions, after that the Academy of Sciences took over the printing, it became standard to present the monthly calendric information over two pages: the left page provided information on the Church feasts, while the right covered instructions for biblical readings and a list of official public holidays (Pogosjan 200r: 33I). In such type of calendars St. Sampson is mentioned on the left page under June 27, while the "triumphant remembrance of the victory near Poltava” ("торжественное воспоминовение побъды подъ Полтавою”) appears on the right page. Yet this was not always the case: for example, the battle was absent from the 1728 civil Menologion but present in the 1736 edition $^{17}$. This inconsistency not only confirms scholarly observations about changes in the way the anniversaries of the battle were celebrated in the eighteenth century but also proves that the very inclusion of such a celebration in the svjatcy did not immediately turn into the established practice. In the extremely concise lists of Church feasts published in the so-called "curious Menologions" “Аюбопытные месяцесловы”) of the second half of the eighteenth century, such as the one compiled by Vasylij Ruban in 1776 , no reference to 'victory' is found. The sixty-seventh anniversary of the "victory near Poltava" is mentioned therein only in an extensive list of tens of various secular and Church events in the "chronicle of matters worth remembering for 1776 ". This section, for example, refers to the Creation of the world, the founding of Rome, the invention of powder and guns, the be-

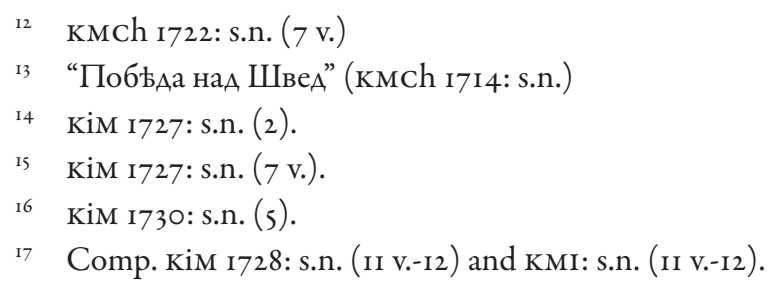




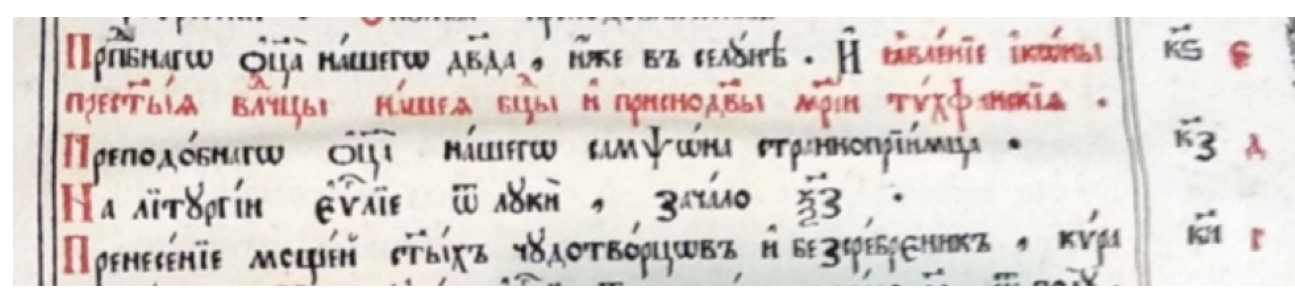

FIGURE 3

A fragment of the Church Menologion lacking a reference to the Poltava 'victory'.

(Svjaščnnoe Evangelie, Moskva 1779).

ginning of carriage rides, the shaving of beards, the foundation of schools in Kyiv and - last on the list - a year since the "destruction of the Zaporožian Sič" ${ }^{18}$.

While the civil Menologions of the first decades of the eighteenth century included the battle with the Swedes in 1709 (as a starting point in a chronology, as a public holiday, and sometimes as an entry in a short list of Church feasts), one finds a completely different situation in the svjatcy which was added to liturgical books. The new feast of the Poltava 'victory' was not entered in the Church calendars of the Moscow liturgical editions published after 1709 nor in those which appeared in the following decades ${ }^{19}$ (cfr. FIGURE 3 ). This means that, according to what the analysis of the Church calendar tells us, it was not part of the sacred symbols sanctified by the Church and ideologically remained a profane, secular holiday. The 'victory' was neither included in the Kyivan Menologions which were printed in 1741, 1765, 1773, $1775^{20}$ nor in the Černihiv Church calendars (for instance in the Apostle of $1770^{21}$ ).

Notably, the battle with the Swedes started to be recorded in the svjatcy in the 1780 s; for example, in the 1783 Kyiv sobornik there is an entry related to this event on 27 June ${ }^{22}$. Not only did this feast, which was observed until the end of the eighteenth century, occurred in the Kyiv and Moscow Church calendars ${ }^{23}$, but following the annexation of the Right-Bank Ukraine to the Russian Empire as a result of the partition of the Polish-Lithu-

I8 MLM: I4, 2I-24.

I9 See, e. g. KA I7I3: 252; Ev: 45I v.; Tr I76I: 336; sl I763: 213 .

20 MLM: I4, 2I-24.

21 KA 1770: $237 \mathrm{v}$.

22 "And a holiday about the victory given by God to the All-Russian autocrat Peter the Great over the Swedish king Charles XII at Poltava, the year from the Incarnation of the Lord 1709" ("И праздникъ ш побъдъ бгомъ дарованной Всєроссійскому Самодєржцу Пєтру Вєликому, наА швєАскимъ королємъ кароломъ вторымнаАєсАть подб полтавою, аӵै”, AK $1783: 328$ v.).

23 See, e. g., Bib: I2O v.; KA 1790: 302 v.-303; AK 1798: 323 v.; Sl I793: 89; Sl I794: 22I v.-222; sl 1795: $231 \mathrm{~V}$. 


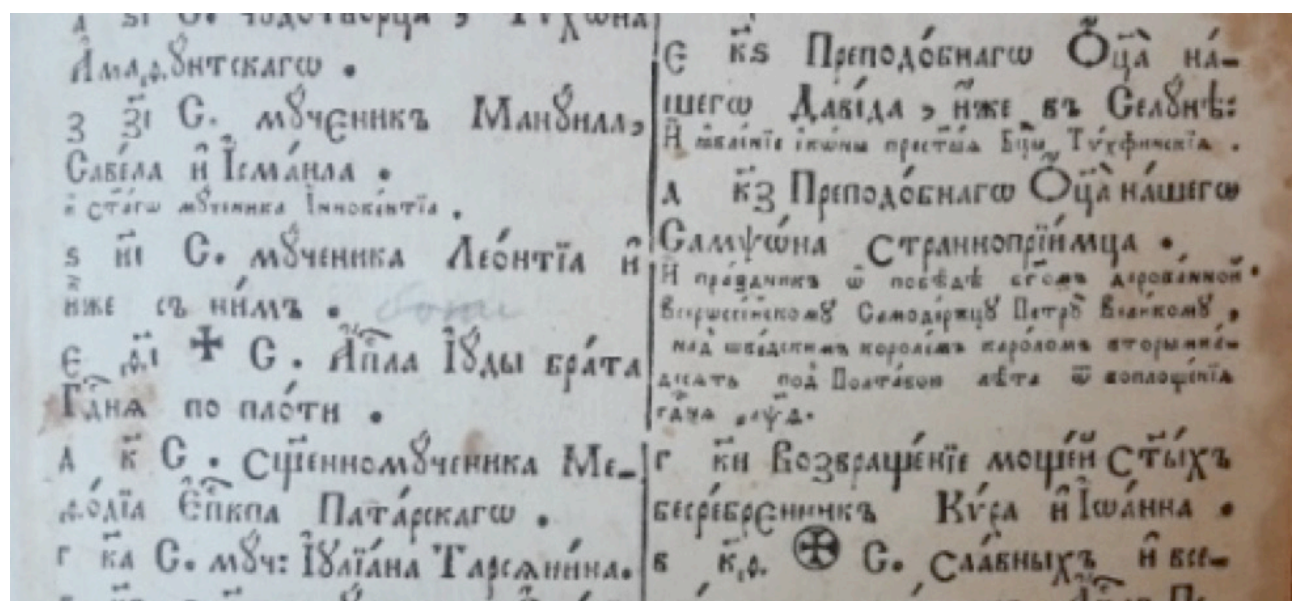

FIGURE 4

A fragment of the Uniate Church Menologion mentioning the 'victory' of Poltava (Akafisty različnyji, Počajiv 1798)

anian Commonwealth, it was incorporated into the Počajiv Uniate Church Menologions ${ }^{24}$ (cfr. FIGURE 4).

I have not found any explicit synodal decree demanding a reference to the battle of Poltava in Church calendars. I believe that its inclusion in Menologions was prompted

${ }^{24}$ AR: s.n. (the $7^{\text {th }}$ folio of the calendar). It is difficult to establish whether the inclusion of the battle of Poltava in the Uniate liturgical books was a result of state coercion or an indipendent decision by the Počajiv typography, in an attempt to adapt to new political circumstances. Poltava is not mentioned in the extremely popular practical calendars of the Carmelite printing house of Berdyčiv (for example in the calendar for 1802 ) - neither in the list of church feasts (those calendars contained a very laconic Orthodox svjatcy), nor in the rubrics "Epoki znakomitsze" ("Most famous epochs") and "Dni uroczyscie obchodzone w Jmperium Rossyiskim, i wolne od zabaw publicznych" ("Days solemnly celebrated in the Russian Empire and free from public occupations". The last rubric also contained church holidays, see KRR). There is no mention of the battle of Poltava in other civil calendars published at the beginning of the $19^{\text {th }}$ century in the Russian Empire's periphery, for instance in Warsaw (see KPRG: s.a.). It should be borne in mind that civil calendars differed from Church calendars in structure and contents, and in the latter the Church Menologion was too short to provide detailed references and information. However, it is evident that the Carmelite printing house could not completely avoid mentioning the 'victory'; in the list of June Church feasts, no reference to the Poltava 'victory' in the calendar for 1845 is found, but it did appear in the list of the "Lord's Holidays and state solemn days" ("Remembrance of the Poltava victory"). It is interesting to note that the event was not considered as a day off for government agencies and educational institutions (see KG: s.n. [I6]), and a "memory of the battle near Poltava" in the Vilnius calendar for 1848 is mentioned in the special rubric "Days on which there is a thanksgiving prayer for victories" (see MCh: s.n. [32]). 
by the Holy Synod decree of 27 March 1778 which concerned, however, not the svjatcy but liturgical books in general. According to the decree, the editions containing the order of services should include a cross 'with a semicircle' under 27 June on the field facing the 'victory' entry. The instructions did not specify the colour of the sign but there are good reasons to suppose that it was red. Placing red crosses in the texts was common practice; on the other hand, the synodal order of 27 March 1778 declared that the celebrations for the 'victory' of Poltava were to be equal to the level of veneration for Alexander Nevskij, whose remembrance days were just marked by a red $\operatorname{sign}^{25}$. It cannot be excluded that the Holy Synod marked the date of the battle of Poltava with the very same sign which was commonly employed in Church calendars, thereby stimulating its steady presence in the Church Menologions. This process did not happen all of a sudden: the Menologion that is attached to the Moscow Gospel of 1779 (an edition that served as the standard for other Church publishing houses) does not mention the battle of Poltava ${ }^{26}$.

Interestingly, the Church Calendars that were published in the Russian Empire in the late eighteenth century marked the level of the solemnity of 'victory' in different ways (Menologions provided lists of fixed holidays for each day of the year and usually marked their significance with special signs or colours). In the aforementioned 1783 Kyiv calendar and Uniate Počajiv calendar of 1798 , the reference to the 'victory' event is marked as an ordinary feast. In the 1784 Moscow edition, holidays are not accompanied by any signs, and the battle of Poltava is only highlighted with a slightly darker font (similarly to the feast of Saints Peter and Paul). However, the 1798 Lavra edition followed the synodal order of 1778 - here the Poltava 'victory' is marked with a black cross in a semicircle, which indicates the status of medium solemnity of a Church holiday. In the Moscow Menologion of 1793 and 1795 (cfr. FIGURE 5), the entry was also marked as medium. On the contrary, in the Moscow edition of 1794 the battle of Poltava was considered one of the greatest feasts and marked in the same way as, for example, Christmas. In this latter case, we are probably dealing with a typo: in the synodal editions no special marks were used and the level of the feasts' solemnity was indicated by cinnabar ink; it cannot be ruled out that a typographer had bad control over colour values. By the end of the eighteenth century, the 'victory' at Poltava had become a Church holiday and one, according to the calendar markers, with a medium status equal to feasts such as the Feast of St. Michael (8 November), the feasts of the Apostles Matthew (16 November) and Mark (25 April), Andrew the First-called ( 30 November), Gregory the Theologian (25 January), John the Baptist (24 February, 25 May), the Cathedral of the Twelve Apostles (30 June), Elijah the Prophet (20 July), and several others.

25 The decree requires that a red mark should be printed on the calendar field opposite the memory of Alexander Nevskij on 23 November and, according to the synodal order of 5 March 1778 , the cinnabar cross in the field was to mark the memory of the transfer of the relics of the saint on 30 August (PSPR II: 202 [N $\left.\mathrm{N}^{\circ} 76\right]$ ).

26 SE I779: 244. 


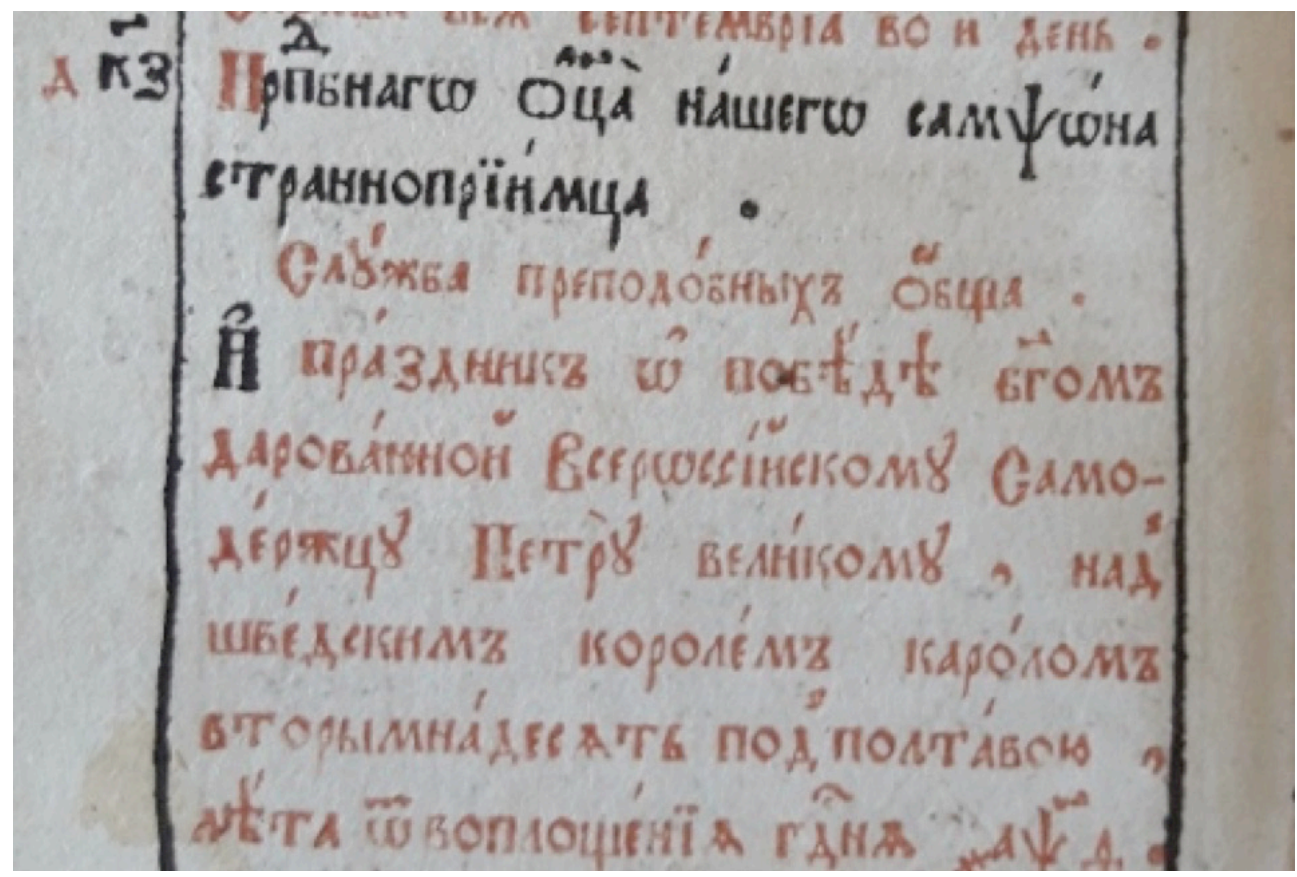

\section{FIGURE 4}

A fragment of the Church Menologion referring to the 'victory' at Poltava

(Služebnik, Moskva 1795)

Why was the battle of Poltava not included in Church calendars during the reign of Peter I? What can be said about the fact that only in the late r77os its entry is found? There are several factors to consider in answering these questions. The sacralisation of the 'victory' of Poltava in the last decades of the eighteenth century during Catherine II's reign should not be surprising. Before entering further into the discussion, I shall turn to the internal and external circumstances that contributed to the transformation of the battle into a feast of the liturgical calendar.

\section{The Battle of Poltava: Sacralisation and Celebration}

It is well-known that Catherine II presented herself as Peter I's follower and, more precisely, as his ideological successor (Uortman 2002: 227). It is this image of the sovereign as the 'granddaughther' of the first emperor that was present in 1760 s and 1770 s Russian literature. Claiming the role of Peter I's successor was a crucial ideological strategy for corroborating Catherine's usurpation of the imperial throne and her right to hold monarchical power and the deriving divine legitimacy. Already during the coup, she had changed into the older uniform model worn by the Preobraženskij Regiment at the time of Peter I (her portrait in this very uniform appeared in the Throne Hall of the Peterhof Palace already 
in 1773; smaller replicas were also made thereafter, cfr. Ivleva 2020: 91 ${ }^{27}$ ). Vasilij Majkov compared the image of Catherine (during the coup) with Peter I (in the battle of Poltava) in his Ode on the Occasion of the Election of Deputies to Compose a Draft of the New Code of ${ }_{17} 67$ (Ода на случай избрания депутатов для сочинения проекта Нового Уложения I767 2oдa) - she paraded in front of the troops like Peter did: "Such was Peter great in glory, / When during the battle at Poltava / He was hurling thunder at the audacious Swedes"28.

The empress's achievements were presented as strengthening and continuing her 'grandfather's' actions. At the beginning of Catherine II's reign, 'Peter's legacy' was positioned as sacred; the empress was proclaimed the restorer of Peter's ideological inheritance, the heiress of his wisdom and knowledge, and the one who completed the work he had begun. By the end of the 1760 s the activities of the first emperor had become a 'respectable background' for emphasising Catherine's own merits. This is well testified, for instance, by the history of the construction of a new monument dedicated to Peter I in St. Petersburg. The empress proposed this endeavour already in 1763 , and also considered several other projects. Work on the monument began in 1767 and was completed in 1782 . According to Vera Proskurina, the monument to Peter was actually seen as a celebration to the achievements of Catherine II herself. This was by no means the only commemorative object honoring the legacy of her 'grandfather'. In 1768 the construction of St. Isaac's Cathedral began, which was to replace the church of the same name founded by Peter I. In 1770 a triumphal column was erected near the burial of the first emperor in honour of his own and his 'granddaughter's' naval victories, symbolically connecting the two reigns; Catherine II's victory over the Turks at Chesma in 1770 was presented as a continuation of Peter I's deeds, and on that occasion a prayer service was held for the first emperor (Uortman 2002: 176); in the same year Aleksej Antropov painted Peter's ceremonial portrait (Ivleva 2020: I05). The literature also presented these events and the relevant ideological constructions (Proskurina 2006: 36-37, IIO-II4, II9, I21, I23, I25, I27). It was only in the early I780s that Catherine II began to dissociate herself from Peter's 'past age' and progressively delete Peter's myth (Proskurina 2017: 97-101).

As until the early I 78 os Catherine II proclaimed herself the successor of the first emperor and associated her own accomplishments with his efforts, the insertion of the Poltava 'victory' in the Church calendar in the late I770s can be seen not only as a reminder of

27 Analysing the descriptions of Catherine II's clothing in 1762 , the visual images of Russian emperors from portraits and other artworks, and the history of the Semenovskij and Preobraženskij regiments' uniforms, Victoria Ivleva argues that Catherine II's uniform (which actually was the same worn by the Semenovskij Regiment and which was mistakenly understood to be similar to the one worn by the Preobraženskij Regiment) emphasised the legitimacy and longevity of power coming not only from the first emperor but also from her other predecessor, namely Elizabeth. Ivleva interprets Catherine's change of dress from the perspective of political theology (Ivleva 2020: 106-107).

28 “Таков был Петр велик во славе, / Когда на брани при Полтаве / Бросал на дерзких шведов гром" (Proskurina 2006: 23-25, 33, 7I-74; cit.: 38). 
recent military achievements (for instance, the victory in the war with the Turks in 1768 1774) but also as the completion of a further plan. Indeed, under Peter I there was a plan (although never realised) to raise the victory over the Swedes to the level of a sacred event, the significance of which was not limited to an imperial ideological symbol. In particular, sporadic references to the battle in the short lists of Church holidays in the civil Menologions published in the first decades of the eighteenth century pointed towards such an intention. As also shown by Nadieszda Kizenko the liturgical veneration of Poltava during Peter's time confirms the implied sacralisation process of the battle; Kizenko has drawn attention to the uniqueness of the "victory" commemoration in the liturgical practice of the imperial era. It was the first special, full-length service of this type (and not just a service of thanksgiving); rather than being connected with saints, icons, or the cross that gave patronage and support in battle, it was related to specific historical figures and, finally, it was replete with unprecedented political allegories. This liturgical celebration did not link the event to human reality but "to the level of Church time", "raised to the honour accorded to saints", to "cosmic and permanent liturgical time". According to Kizenko, for the first time since the Christianisation of Rus' in the late tenth century, a secular ruler made such a dramatic intervention in the liturgical sphere. However, after the end of the Great Northern War Peter I himself proposed to soften the emphasis in the service devoted to the Poltava 'victory', removing the designation of the Swedes as heretics and the allusions to Charles XII as "the devil" and "Pharaoh". In 1736 the Holy Synod was ordered to edit again the text in order to soften its hostile position against the Swedes. Despite this, between 174I to 1913 it was the original, unedited version of the service which was printed (Kizenko 2009-2010: 227-228, 230, 234, 238-239).

Kizenko examines "all traditional forms of commemoration" used by Peter I and the Church hierarchy (such as the construction of a new church in St. Petersburg dedicated to St. Sampson who was commemorated on 27 June, as well as sermons and prayers) and the unprecedented step of compiling a special service. She does not discuss, however, the inclusion of Poltava in the Church calendar. This is not surprising because under Peter I, despite the raising of the battle through liturgical practice to 'the level of Church time', the last step for its sacralisation had not yet been taken: 'victory' was not put in the Church Menologion. This was finalised under the 'ideological successor' of the first emperor, that is to say Catherine II. The following episode, which is found in historical literature, suggests that the empress drew her attention to the 'victory': allegedly, after her ascent to the throne in 1766 , a celebration was established in honour of the Kapluniv Icon of the Mother of God (September II) which, according to legend, helped Peter I near Poltava. Subsequently, the empress granted the request of the Ochtyrka authority and in 1772 allowed the church in Kaplunivka to be exempt from paying taxes and instead use the saved funds for the building of a new stone church (Čugreeva 2009a: 447; 2009b: 306-307). It has not been possible for me to document Catherine's decree about the celebration to honour the icon on II September, there is no corresponding order in the published collections of decrees and synodal resolutions. It is safe to assume that such a resolution might have concerned 
only local veneration because there is no mention of the Virgin of Kapluniv in the svjatcy on iI September.

Let us now look at some external circumstances that under Catherine II may have drawn attention - at least partially - to the battle of Poltava. The Russian Empire was not in overt conflict with Sweden at the time of the inclusion of 'victory' in the Church Menologion, a circumstance which could have favoured a 'calendar' sacralisation of the battle. Nevertheless, St. Petersburg's relations with Stockholm were not good. Russia had lost its influence over Sweden, which strengthened the army with outside support. The desire of the empire to control the Swedish throne was well reflected in the treaty with Prussia in 1769. As was put in a secret clause of the treaty, St. Petersburg and Berlin stated that they considered it necessary to maintain the current form of government in Sweden, that is, weak royal power. If the Swedish king regained his unlimited powers, Prussia was supposed to invade Swedish Pomerania at Russia's request. Earlier, in 1766, the preservation of weak royal power was agreed upon in the treaty between Russia and Denmark which was renewed in $\mathbf{1 7 7 4}$. According to the treaty of 1773 , in the event of a Swedish-Russian war, Denmark had to support Russia with arms. Acting more directly, St. Petersburg strongly influenced part of the Swedish nobility and hindered political reforms.

Gustav III, Catherine II's cousin, not only aspired to revive Swedish power, but from the beginning of his reign in $177 \mathrm{I}$ was successful in dispelling Russian influence on Sweden and, going against the Russian hopes, in 1772 he restored a strong monarchy. The king was supported by France, which, after the first partition of the Polish-Lithuanian Commonwealth, even managed to get London to demand from St. Petersburg, Vienna, and Berlin that $S$ weden be saved from a similar fate. France and Britain also agreed that in the event of a Russian attack on Sweden, France would support the Swedish navy and army in every possible way and Britain would offer no assistance to Catherine II. After the 1772 revolution in Sweden, the Russian empress described Gustav negatively. In a letter to Johanna Bielke dated August 24, 1772, she wrote: "The laws of no country have ever been so violated as in Sweden on this occasion, and I can assure you that this king is as much a despot as my neighbor, the Sultan" ${ }^{29}$. In December of the same year, recalling Swedish policy in Norway, Catherine II once again remarked: "I can see that he [Gustav III, M.Y.] has little respect for his assurances and, were I to say it as it is, there is nothing sacred for him" ${ }^{\circ}$.

After the events of 1772 , the diplomatic relations between Sweden and Russia cooled off and rumours of a possible war between them spread through Europe. Both St. Petersburg and Copenhagen strengthened the border garrisons, and Catherine II refused to accept a diplomatic agent sent by Gustav III. The conflict was avoided in 1772, and the Swedish king

29 "Никогда законы ни в какой стране не были так нарушаемы, как в Швеции при этом случае, и я вам ручаюсь, что этот король такой же деспот, как сосеА мой, султан” (Pis’ma Ekateriny II k Ioganne Dorotee B'el'ke, cfr. EFZ: 337 ).

30 “я по всем вижу, что он мало уважает свои заверения и, если нужно сказать напрямик, ААя него нет ничего святого” (EFZ: 338 ). 
predicted a Russian attack the following year. Catherine II also wrote in a letter to Voltaire in October 1772 about a possible war had Sweden taken over Norway. Already in the mid-I770s, Gustav III conceived the idea of conquering Norway and attacking Russia. In October 1775 he wrote that Catherine II postponed the war with him only because of her activities in the Polish-Lithuanian Commonwealth and Turkish affairs; he should thus prepare for defence and first attack Russia in order to end the confrontation as soon as possible. Gustav III's visit to Russia in 1777 allegedly eased tensions between the two states; nonetheless, as the Swedish envoy in Paris reported shortly after the visit, Catherine II's assurances of friendship were insincere and she did not believe in the sincerity of Stockholm's assurances. Despite the achieved peace, in the following years both parties observed each other with some caution, and without fully leaving behind their original intentions ${ }^{31}$.

Another issue to be addressed is whether Gustav III's visit to Russia and the contacts with Catherine II prompted in the following year the Holy Synod to issue an order to mark the Poltava 'victory' with a cross in a semicircle in the liturgical books, before entering it in the svjatcy. For example, the Swedish Foreign Minister count Ulrich Schaeffer, who accompanied the king on the trip, considered that the monarch not only had not come close to establishing friendly relations with the empress but also failed to impress Catherine II favourably. He attributed the success of the visit to St. Petersburg to his own efforts, and not to Gustav III's (Grot 1901: 231-232). It is interesting to note that some associate the Swedish king's trip to the Russian Empire with tsarevich Pavel Petrovičs joining of the Masonic lodge. This action, in turn, was disapproved by Catherine, who distrusted and fought against any form of Freemasonry. The empress was not fond of Russian lodges and disliked their contacts with Gustav III, but in 1779 she learned that Pavel had become a member of the lodge and that Freemasons had criticised the monarch, and Catherine began to openly rebuke Freemasonry. The theme of Freemasonry was then targeted by her satirical pen and repeatedly reported in literary works of the 1780 (Proskurina 2006: 91-92; 2017: I2I-I27).

It seems likely that the aforementioned circumstances (Catherine's perceived continuity of her 'grandfather' Peter I's affairs, the attempts to symbolically combine her own military victories with past accomplishments, the mostly strained relations with Sweden, and the empress's dislike of king Gustav III) stimulated the entry of the commemoration of the battle of Poltava in the Church Menologion and finally determine its status as a sacred symbol at the end of the r77os. Unfortunately, the lack of details about what happened behind the scenes (for example, the persons involved, specific orders, discussions, and so forth), which could provide helpful data to understand some aspects related to the entry of Poltava in the Church calendar, has forced me to only consider broader contexts in the analysis. It is not my intention to relate the final sacralisation of the battle with any particular internal secular or ecclesiastic event of the time (such as the specific measures of political unification of the empire or the correction of the liturgical books). Without accu-

${ }^{31}$ Here I rely on the analysis of the Russia-Sweden relationships during the reign of Catherine II expounded by Brikner (I869: 9-II, I4, I9-27) and Grot (I9OI: 217-221, 23I-232). 
rate and reliable data, any conclusion about other issues, such as the relationship between secular and Church authorities, remains at a theoretical level. There is one point, however, that I believe must not be overlooked: in the process of uniting the empire and shaping a common social, ecclesiastical, and political imperial space, the Poltava 'victory' was to emphasise the importance and the strength of unity, to bolster cohesion and contribute to the need to support the central power, while also warning potential opponents of Catherine's reforms. It is plausible that achieving imperial unification was the main stimulus for granting the status of sacred symbol to the event commemorating the victory over the Swedes. Previous monarchs do not seem to have used similar mass mobilisation strategies.

My concluding remarks about the process of sacralisation of the battle invite the reader to embrace a wider perspective and to consider two broader issues: eighteenth-century aspects related to the celebration of the Russian victory over the Swedes in 1709, and the role of Church symbols in imperial politics. In historiography there are two opposing views on the celebration of the Poltava battle in the Russian state; incidentally, it should be noted that until now scholars have considered Poltava mostly as a vysokotoržestvennyj and viktorialnyj day, as a state or court holiday rather than as a Church feast. Annual secular celebrations on the occasion of 'victory' were introduced straight after: the first anniversary was celebrated in I7IO. In addition to this battle Peter I established six other memorable events of the Great Northern War. The nature of their celebration varied from court banquets to molebens (services of entreaty) to fireworks. The anniversaries of Poltava and the Peace of Nystad were most solemn. Straightaway after the battle and in the following years, the commemoration of the victory over the Swedes was to be celebrated by relying on two mechanisms used by the Church: worship and sermons (Ageeva 2009: 265-266). From the I730s the celebration of the 'victory' started to loose its power. As already mentioned, the liturgical celebration also changed, and only a prayer of thanksgiving was held instead of a special full-length service. Elena Pogosjan noted that under Anna Ioannovna the battle of Poltava was not publicly celebrated at court despite its presence in the civil calendar. In the early I740s, Poltava was included among the holidays in which one-day rest from public works was stipulated (as well as for the other 'state holiday', Pogosjan 200I: 359, 361, 389 ). In the following decades one of the most notable festivities was a local celebration in Poltava itself, with Catherine II's participation in $1787^{32}$. During her reign, according to Alexander Kamenskii, the commemoration of the battle was sidelined by new victories and its memory was blunted, at least at the court (Kamenskii 2009-2010: 198-200). N. Bolotina claims, by contrast, that Catherine's reign was marked by a surge of interest in the battle of Poltava. Her conclusion is not based on new facts, as the author refers to the events which are

32 Later in the nineteenth-century commemorative practices and celebrations of the anniversary of the battle mostly took place in Poltava itself. It was only in 1909 that the celebration of the $200^{\text {th }}$ anniversary became an all-imperial and ideologically informed endeavor - the circumstances of the time required patriotic mobilisation of society for which purpose the anniversary was used (Ageeva 2009: 268-27I). 
discussed by the opposing view. In her article Bolotina gives examples of local celebrations dedicated to the battle; among them the most interesting is a three-day visit by Catherine II to Poltava on 7-9 June 1787 . On this occasion, for the first time in Russian history, a historical battle reenactment was carried out on the field of Peter I's victory over Charles XII (Bolotina 2009: 345-355; 2010: 292-30I). It can be observed that these scholarly arguments are concerned with public celebrations, which at the time of Catherine II's reign were really few. Yet the Poltava 'victory' was finally transformed into a sacred Church feast during her reign, continuing to be an important instrument of ideology. The liturgical celebration of this event in parish churches remained clearly solemn; for example, according to the sexton Fedor Kirnec'kyj from Chovzovka village (Hluchiv ujezd) on 27 July 1788 "vesper's service and morning thanksgiving prayer for the victory over the Swedes in 709 near Poltava [were held]. The thanksgiving moleben was held after liturgy with bell-ringing" ${ }^{33}$. Notably, in this case not only was a moleben held (which was usual in the case of military victories) but also a full-length service.

The reputation of the enlightened monarch did not prevent Catherine II's from relying on Church's ideological strategies - not all of her actions were, in fact, secular in nature as her contemporaries thought (Proskurina 2006: 213). An undated note concerning measures to help the masses ("Helping the public in adversity" - "Помощь народу в бедствиях"), such as easing laws, reducing taxes, and prohibiting the splendour of funeral pomp, contained what follows: "to issue a decree about prayers, fasts and alms" ${ }^{4}$. In addition, it is well-known that the first and only person canonised in the Russian Empire for general veneration in the eighteenth century was Dmytrij, the Metropolitan of Rostov (Golubinskij 1998: 158-159, 170-172). He was included among the saints during the reign of Elizabeth Petrovna. In addition to the new saint, two more entries appeared in the Church calendar in the eighteenth century. The first was entered under Peter I and is also indirectly connected with the victory over the Swedes: in 1723 the relics of Alexander Nevskij were transferred from Vladimir to St. Petersburg on 30 August - just in time for the anniversary of the signing of the Treaty of Nystad in 1721. The corresponding reference at the end of the summer appeared in the Church Menologion in the first half of the eighteenth century ${ }^{35}$ (after that, the Church calendar of the synodal era was replenished with the mention of the Metropolitan of Rostov). The second entry is the date of the Poltava 'victory', which came to be included in the Church calendar under Catherine II, and the specific ecclesiastical strategies which I mentioned above were used by the monarchy during the entire eighteenth century. This was predictable, because they were the easiest expedient for the authorities to exert power and for the masses the most acceptable way to accept, or at least to start changing attitude towards, imperial rule.

\footnotetext{
33 ŠAFK: 57.

34 “издать указ о молебствиях, постах и пожертвованиях" (zE: 666 [zametka]).

35 See, for instance, AK 174I: $338 \mathrm{v}$.
} 


\section{Concluding Remarks}

In the liturgical calendars, references to the 1709 victory over the Swedes outlasted the 'long eighteenth century'. In addition, in the nineteenth century this commemoration was included not only in the calendars added to liturgical books but also in the Menologions addressed to a wider audience, which appeared outside of the Church printing presses, as well as in special synodal publications of the full lists of saints venerated by the Orthodox Church. One finds the "feast of the victory granted by God" to Peter I over Charles XII in the full Orthodox Menologions of the first decades of the nineteenth century. Yet the indication of the solemnity of the battle's commemoration differed; for example, in the calendar published by the Holy Synod in I8I8 it remained as medium in status ${ }^{36}$. The battle was marked by a feast of an ordinary level of solemnity in the full Church Menologion of the next decade ${ }^{37}$. In the few later lists of the "Lord's feasts and state solemn days" it was set up as a holiday during which government agencies and schools were open (unlike the birthdays and namedays of some members of the imperial family) ${ }^{38}$. The great Orthodox Menologion compiled by the college assessor Ivan Kosolapov and published with the permission of Church censorship in 1874 did not fail to remember Poltava. Here there was an entry under June 27: "The holiday about the victory given by God to the All-Russian Autocrat Peter the Great [italics in edition, M.Y.] over the Swedish king Charles XII near Poltava". The compiler decided to explain the presence of such a position among the lists of saints and sacred events; at the bottom of the page and in a smaller font, he clarified the ecclesiastical significance of the feast as follows: "In 1709. 'We have ordained that this notable day be kept as a festival, that another generation might know, even the sons about to be born, that they in turn might arise and declare them unto their sons, that they might set their hope in God and not forget the works of God, but seek His commandments.' Sessional hymn after the first kathisma" ${ }^{39}$. The 'victory' did not disappear from civil reference Menologions, which included short lists of Church feasts among others rubrics; one of these for the year 1875 mentioned St. Sampson in the rubric "Orthodox Menologion" on

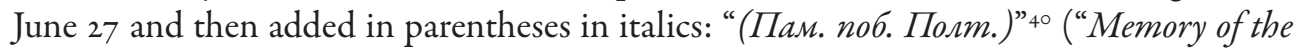
Poltava Victory"). The proximity of commemoration of Poltava to the names of canonised ascetics and miraculously sanctified icons or events was not unexpected for nineteenthcentury scholars. In the full Eastern Menologion by Archimandrite Sergij, on 27 June 'victory' coexists side by side with the martyrs, the most revered, the blessed, the apostles, myrrh-bearers, and so forth (Sergij I876: 169 [č. I]).

\footnotetext{
36 PChM: 94.

37 PM I827: 44.

38 PM I829: 4I2.

39 MPKC: 153. I used the Sessional hymn's translation by N. Kizenko (2009-2010: 252).

40 MSSK: 17.
} 
It can be noted that in Church Menologions the commemoration of the victory over the Swedes was also included in the liturgical books of the beginning of the twentieth century; for instance, Poltava was marked as a medium feast, not an ordinary one, in the calendar included in the Typicon ${ }^{41}$. The commemoration of the 1709 battle survived the Russian Empire not only as a state holiday but also as a Church feast, and is found in the Menologions of the Russian Orthodox Church published in the second half of twentieth century; just to mention an example, the 'victory' is not an ordinary feast in the calendar added to the Apostle of $1985^{42}$. Not only, in fact, in the Soviet Union the myth of the Poltava 'victory' did not disappear, but it was remembered with renewed vigour; the museum dedicated to this event was restored in the middle of the twentieth century with apparent ideological emphasis in the exposition. Opened in 1909 , the museum remained active until 1918, and a new remarkable state institution was established in 1950; in 1981 the museum became part of the state-protected monument conservation area (Piskova 20II: 32I). The anniversaries of the battle also continued to be celebrated in Soviet times - it was a somewhat local feast in 1939, but was celebrated under All-Union government supervision in 1949. The establishment of the State Republican Museum of the History of the Battle of Poltava in 1950 was, in fact, authorised by a resolution of the Council of Ministers of the USSR (Sal'nikova 2009: 417-419). It comes as no surprise then that the very event of the battle was included in the Church books of the time and held in high regard.

\section{Abbreviations}

AK 174I:

AK 1765 :

AK 1783:

AK 1798:

Ap:

AR:

ASBA:

Bib:
Akafisty skanony, Kyjiv I74I.

Akafisty skanony, Kyjiv 1765.

Akafisty skanony, Kyjiv 1783.

Akafisty skanony, Kyjiv 1798.

Apostol, Moskva I985.

Akafisty različnyji, Počajiv 1798.

Akty, sobrannye $v$ bibliotekach $i$ arbivach Rossijskoj imperii Archeografičskoju èkspedicieju Imperatorskoj Akademii nauk, IV, Sankt-Peterburg 1836 .

Biblija, Moskva 1784 .

${ }_{41}$ The initial pages of this typicon of the early twentieth century with accurate bibliographic information have not survived, as noted on the website of the Library of the Holy Father's Literature where can be accessed (T: 336 v., cfr. <http://www.orthlib.info/Typikon/T48-j.pdf >, accessed on 08.02 .2021 ).

42 Ap: $249 \mathrm{~V}$. 
EFZ:

Ev:

KA I7I3:

KA 1770:

KA 1790:

KG:

KiM 17I8:

Kiм 1719:

KiM 1720:

KiM 172I:

KiM 1727:

KiM 1728:

KiM 1730:

KMCh I7IO:

KMCh I7II:

KMCh I712:

KMCh I7I4:

KMCh I718:

KMCh I722:

KMI:

KMIG:
A. Kamenskij (sost.), Ekaterina II. Fasad i zadvorki imperii, Moskva 2007.

Evangelie Iisusa Christa, Moskva 1716.

Kniga dejanij i poslanij svjatych Apostol, Moskva I713.

Kniga dejanij svjatych Apostol, Černihiv 1770.

Kniga dejanij svjatych Apostol, Kyjiv 1790.

Kalendarz Gospodarski utożony podtug starego stylu na Rok Pański $M D C C C X L V$, Berdyczów s.a.

Kalendar' ili mesjacoslov na leto ot Roždestva Gospoda našego Iisusa Christa, I7I8, Sankt-Peterburg 1717.

Kalendar' ili mesjacoslov na leto ot Roždestva Gospoda našego Iisusa Christa, I7Ig, Sankt-Peterburg 1718.

Kalendar' ili mesjacoslov na leto ot Roždestva Gospoda našego Iisusa Christa, I720, Sankt-Peterburg 1719.

Kalendar' ili mesjacoslov na leto ot Roždestva Gospoda našego Iisusa Christa, I72I, Sankt-Peterburg 1720.

Kalendar' ili Misjacoslov na leto ot Roždestva Hospoda našego Iisusa Christa 1727, Kyjiv 1726.

Kalendar' ili mesjacoslov na leto ot Roždestva Gospoda našego Iisusa Christa 1728 , Sankt-Peterburg 1727.

Kalendar' ili Misjacoslov na... 1730, Kyjiv s.a.

Kalendar' ili mesjacoslov. Christianskijpo staromu śtilju, ili izčisleniju. Na leto ot voplošcenija Boga Slova I7Io, Moskva 1709.

Kalendar' ili mesjacoslov. Christianskijpo staromu śtilju, ili izčisleniju. Na leto ot voplošcenija Boga Slova I7II, Moskva,I7 Io.

Kalendar' ili mesjacoslov christianskij. Po staromu štilju, ili izčisleniju. Na leto ot voploščenija Boga Slova I712, Moskva I7II.

Kalendar' ili Misjacoslov christianskij, po staromu stilyu, ili izčisleniju. Na Leto ot Voplošcenija Boha Slova I7I4, Kyjiv 1713.

Kalendar' ili mesjacoslov christianskij. Po staromu štilju, ili izčisleniju. Na leto ot voplošcenija Boga Slova, 1718, Moskva 1717.

Kalendar' ili mesjacoslov christianskij. Po staromu stilju ili izčisleniju. Na leto ot voplošcenija Boga Slova, I722, Moskva 1721.

Kalendar' ili mesjacoslov istoričeskij na leto ot Roždestva Christa I736, Sankt-Peterburg s.a.

Kalendar' ili mesjacoslov istoričeskij i genealogičeskij na leto ot Roždestva Gospoda našego Iisusa Christa I73I, Sankt-Peterburg s.a. 
KPRG:

KRR:

MCh:

MLM:

MPKC:

MSSK:

PChM:

PM I827:

PM I829:
Kalendarz Polski, Ruski i Gospodarski na Rok Pański I8I2, Warszawa s.a.

Kalendarz Rzymski i Ruski na Rok Panski MDCCCII, Berdyczów s.a.

Mesjaceslov Chozjajstvennyj na I 48 god, Vil'no s.a.

Moskovskij ljubopytnyj mesjaceslov na 1776 god, i na vse vysokosnyja leta, krome prostych, pokazujusčij čisla, ili dni mesjacov po staromu i novomu stilju, to est' greko-rossijskago i gregorianskago, nemcami i vseju počti Evropoju upotrebljaemago, takož drevnjago rimskago kalendnago, ili nynešnjago učenago mesjaceslova: $S$ priobščeniem letočislenija i drugich dostopamjatnostej istoričeskich, geograficeskich i pročich. Izdalv svet Vasilij Grigor'evič Ruban, kolležskoj assessor i Vol'nago Rossijskago sobranija pri Imperatorskom Moskovskom universitete člen, Moskva [1775].

I. Kosolapov, Mesjaceslov pravoslavnoj kafoličeskoj cerkvi, spriloženiem polnogo indiktiona, tridcati pjati tablic ctenij iz Evangelija i Apostola na každuju nedelju goda $i$ alfavitnogo ukazatelja imen svjatych, upominaemych v mesjaceslove, Kazan' 1874.

Mesjaceslov, svjatcy i spravočnaja knižka na 1875 god, Sankt-Peterburg 1874 .

Polnyj christianskij mesjacoslov vsech svjatych, prazdnuemych Pravoslavnoju Grekovostočnoju Cerkoviju, s kratkim istoričeskim i chronologičeskim opisaniem ich žizni i končiny, is označeniem vsech Gospodskich i Bogorodičnych prazdnikov, toržestvennych i viktorial’nych dnej, krestnych chodov i carskich panichid; soderžaščj pri každom mesjace na 30 let služaščija raznyja tablicy o rjadovyh i prechodjaščch cerkovnych prazdnikach, takže o voschoždenii $i$ zachoždenija solnca i o lunnom tečenii; s prisovokupleniem polnogo alfavita $i$ tolkovanija imen Svjatych, kratkogo izjasnenija Paschalii i paschal'nych znakov, $i$ trech rospisej, vsem nachodjašcimsja $v$ obeich stolicach $i$ drugich mestach Rossii dostopamjatnym sobornym, monastyrskim, ružnym $i$ prichodskim cerkvam, s pokazaniem načala $i$ postroenija onych; sobrannyj iz dostovernych istočnikov, Moskva I8I8.

Polnyj mesjacoslov vsech prazdnuemych Pravoslavnoju Grekovostočnoju Cerkoviju svjatych, sobrannyj iz moskovskich i kievskich svjatcov iz prologa $i \check{C}$ et'-Minej, spriobšceniem k nemu na konce tolkovanija imen po alfavitu, izd. I3-e, Sankt-Peterburg 1827.

Polnyj mesjacoslov vsech prazdnuemych Pravoslavnoju Grekovostočnoju Cerkoviju svjatych, sobrannyj iz moskovskich i kievskich svjatcov iz prologa $i$ Čet'-Minej, spriobščeniem k nemu na konce tolkovanija imen po alfavitu; Podrobnoe i vernoe opisanie monastyrej nachodjašcichsja $v$ Rossijskoj imperii, raspoložennoe po azbučnomu porjadku i izvlečennoe iz novejsich otečestvennych pisatelej [v odnom pereplete], Moskva, I829. 
PSPR II:

PSPR IV:

ŠAFK:

SE 1773:

SE 1779:

SE 1763:

Sl 1775:

S1 1793:

Sl 1794:

Sl 1795:

$\mathrm{T}$ :

$\operatorname{Tr} 176 \mathrm{I}:$

$\operatorname{Tr}$ 1775:

ZE:

\section{Literature}

Ageeva 2009:

Bolotina 2009:

Bolotina 20I0:

Brikner 1869:
N.N. Aljančikov (red.), Polnoe sobraniepostanovlenij i rasporjaženijpo vedomstvu pravoslavnogo ispovedanija Rossiiskoj imperii, II, Petrograd I915.

A.V. Gavrilov (red.), Polnoe sobranie postanovlenij i rasporjaženij po vedomstvu pravoslavnogo ispovedanija Rossiiskoj imperii, IV, SanktPeterburg 1912.

I. Sytyj (upor.), Ščodennyk Andrija ta Fedora Kirnec'kych, svjaščenykiv Svjato-Mykolajivs'koji cerkvy s. Chovzovky Gluchivs'koho povitu Nov-

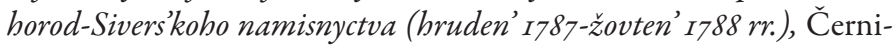
hiv 2006.

Svjaščnnoe Evangelie, Kyjiv 1773.

Svjaščnnoe Evangelie, Moskva 1779.

Služebnik, Moskva 1763.

Služebnik, Kyjiv 1775.

Služebnik, Moskva 1793.

Služebnik, Moskva 1794.

Služebnik, Moskva I795.

Tipikon, s.l. s.a.

Trebnik, Moskva 176I.

Trebnik, Kyjiv 1775.

Zapiski imperatricy Ekateriny Vtoroj, Sankt-Peterburg 1907.

O.G. Ageeva, Prazdniki v čest' Poltavskoj pobedy v XVIII v., in: Ead. (red.), Poltava: K 30o-letiju Poltavskogo sraženija. Sbornik statej, Moskva 2009, pp. 257-273.

N.Ju. Bolotina, Poltavskaja viktorija v pamjati potomkov: toržestva vo vtoroj polovine XVIII-načale XX vv., in: Poltavs'ka bytva I70g roku $v$ istoryčnij doli Ukrajiny, Rosiji, Šveciji ta inšych deržav: zbirnyk materialiv Mižnarodnoji naukovo-praktyčnoji konferenciji, Charkiv 2009, pp. 345-355.

N.Ju. Bolotina, Tradicija prazdnovanija Poltavskoj pobedy v epochu Ekateriny II, in: E.R. Daškova i XVIII vek: Ot Rossijskoj imperii $k$ sovremennoj civilizacii, Moskva 2010, pp. 292-301.

A. Brikner, Vojna Rossii s Šveciej v I788-I79o godach, Sankt-Peterburg I869. 
Chorošev I986:

Čugreeva 2009a:

Čugreeva 2009b:

Golubinskij 1998:

Grot 1901:

Ivleva 2020:

Kamenskii 2009-20I0:

Kazakevič 2009:

Kizenko 2012:

Marker 2007:

Pogosjan 200I:

Proskurina 2006:

Proskurina 2017:

Piskova 20II:

Sal'nikova 2009:
A. Chorošev, Političeskaja istorija russkoj kanonizacii (XI-XVI vv.), Moskva 1986.

N. Čugreeva, O počitanii Kaplunovskoj Kazanskoj ikony Bogomateri, in: Poltavs'ka bytva I7og roku v istoryćnij doli Ukrajiny, Rosiji, Šveciji ta inšych deržav: zbirnyk materialiv Mižnarodnoji naukovo-praktyčnoji konferenciji, Charkiv 2009, pp. 446-449.

N. Čugreeva, Kazanskaja Kaplunovskaja ikona Bogomateri i pobeda pod Poltavoj, in: O.G. Ageeva (red.), Poltava: K3oo-letiju Poltavskogo sraženija. Sbornik statej, Moskva 2009, pp. 302-312.

E. Golubinskij, Istorija kanonizacii svjatych v Russkoj Cerkvi, Moskva 1998 (reprint, $\left.1903^{1}\right)$.

Ja.K. Grot, Ekaterina II i Gustav III, in: Id. (red.), Trudy Ja.K. Grota, IV, Sankt-Peterburg 190I, pp. 210-29I.

V. Ivleva, From Catherine II's Coup to Alexander Pushkin's The Captain's Daughter: A Reflection on Sartorial and Spiritual Searching in Russian Culture, "Вивміоөика: E-Journal of Eighteenth-Century Russian Studies", 2020, 8, pp. 85-I28.

A. Kamenskii, The Battle of Poltava in Russian Historical Memory, in: Poltava I709: The Battle and the Myth, Cambridge (MA) 2009-2010 (= "Harvard Ukrainian Studies", XXXI, I-4), pp. 195-204.

A.N. Kazakevič, Poltavskoe sraženie v pamjati Russkoj Pravoslavnoj Cerkvi, in: O.G. Ageeva (red.), Poltava: K 300 -letiju Poltavskogo sraženija. Sbornik statej, Moskva 2009, ss. 313-333.

N. Kizenko, The Battle of Poltava in Imperial Liturgy, in: Poltava I709: The Battle and the Myth, Cambridge (MA) 2009-2010 (= "Harvard Ukrainian Studies", XXXI, I-4), pp. 227-269.

G. Marker, Imperial Saint: the Cult of St. Catherine and the Dawn of Female Rule in Russia, DeKalb 2007.

E. Pogosjan, Petr I - architektor russkoj istorii, Sankt-Peterburg $200 \mathrm{I}$.

V. Proskurina, Mify imperii: Literatura i vlast'v epochu Ekateriny II, Moskva 2006.

V. Proskurina, Imperija pera Ekateriny II: literatura kak politika, Moskva 2017.

E.M. Piskova, Pole Poltavs'koji bytvy, in: Encyklopedija istoriji Ukrajiny, VIII, Kyjiv 20II, p. 32 I.

O. Sal'nikova, Istorija stvorennja ta rozvytku Deržavnoho istorykokul'turnoho zapovidnyka "Pole Poltavs'koji bytvy", in: Poltavs'ka bytva I7og roku v istoryčnij doli Ukrajiny, Rosiji, Šveciji ta inšych deržav: zbirnyk materialiv Mižnarodnoji naukovo-praktyčnoji konferenciji, Charkiv 2009, pp. 412-42I. 
Sergij I876:

Uortman 2002:

Zitser 2008:
Archim. Sergij, Polnyj mesjaceslov Vostoka, II, Moskva I876.

R. Uortman, Scenarii vlasti. Mify i ceremonii russkoj monarchii, I, Moskva 2002.

E.A. Zitser, Carstvo Preobraženija: Svjaščnnaja parodija i carskaja charizma pri dvore Petra Velikogo, Moskva 2008.

Abstract

Maksym Yaremenko

The Sacralisation of the Battle of Poltava in the Eighteenth-Century Russian Empire

Shortly after its completion, the Battle of Poltava became a key symbol of Russian imperial ideology. Yet the successful completion of the military campaign in Poltava acquired the status of a sacred event only in the last decades of the $18^{\text {th }}$ century. In this article I investigate both the reasons why during Catherine II's reign this military event was granted its own entry in the Church calendar and the internal and external affairs that encouraged the process of sacralisation of the victory over the Swedes by the synodal Church. I argue that the analysis of the Poltava victory as a sacred symbol, which has been largely disregarded by historians, allows us, inter alia, to better assess the mobilising role of the Church feasts in the $18^{\text {th }}$-century Russian imperial policy.

\section{Keywords}

Battle of Poltava; Russian Imperial Ideology; Church Calendar (Menologion); Catherine II. 